\title{
PENGOLAHAN BUAH PEDADA MENJADI SIRUP "BOGEM" DI KAWASAN WISATA HUTAN MANGROVE SURABAYA
}

\author{
Handy Febri Satoto ${ }^{1}$, Aris Sudaryanto ${ }^{2)}$ \\ ${ }^{1,2}$ Universitas 17 Agustus 1945 Surabaya \\ Email: handyfebri@gmail.com
}

\begin{abstract}
Abstrak
Hutan mangrove menghasilkan buah yaitu buah pedada yang dapat diolah menjadi produk olahan. Bapak Mohson adalah penemu produk sirup "Bogem”. Sirup mangrove Bogem ini diproduksi oleh Kelompok Tani Mangrove Wonorejo sebagai oleh-oleh khas sehingga meningkatkan kearifan lokal kawasan wisata hutan mangrove Wonorejo Surabaya. Permasalahan pada usaha sirup mangrove Bogem ini adalah Proses produksi pembuatan sirup Bogem terdapat hambatan pada saat proses pemerasan dengan manual yang membutuhkan banyak tenaga dan penyimpanan sirup Bogem dan buah pedada saat musim panen serta agar buah tidak cepat busuk. Pengelolaan usaha yang masih sangat tradisional dan tidak memiliki pembukuan/pengelolaan keuangan usaha. Kurangnya wawasan mengenai penjualan secara online dan offline agar dapat memperluas dan meningkatkan penjualan. Hasil dari pengabdian ini adalah membuatkan alat pemeras hasil rebusan buah Bogem sehingga tidak memperlambat proses produksi dan pengadaan mesin pendingin agar buah Bogem dapat disimpan saat musim panen dan tidak mudah busuk; pelatihan dan pendampingan pengelolaan usaha dan pengelolaan keuangan; pelatihan teknik dan strategi pemasaran secara online dan offline.
\end{abstract}

Kata kunci: Sirup Bogem; Alat Pemeras; Mesin Pendingin; Manajemen Keuangan; Pemasaran

\begin{abstract}
Mangrove forests produce fruit, namely pedada, which can be processed into processed products. Mr. Mohson is the inventor of the "Bogem" syrup product. Bogem mangrove syrup is produced by the Mangrove Wonorejo Farmer Group as a typical souvenir so as to increase the local wisdom of the Wonorejo Surabaya mangrove forest tourism area. The problem with Bogem's mangrove syrup is that the production process of Bogem syrup has obstacles during the manual squeeze process that requires a lot of energy and storage of Bogem syrup and pedada during harvest and so that the fruit does not rot quickly. Business management that is still very traditional and does not have bookkeeping / business financial management. Lack of insight into online and offline sales in order to expand and increase sales. The result of this dedication is to make a squeezer from the Bogem fruit stew so that it does not slow down the production process and the procurement of a cooling machine so that Bogem fruit can be stored during the harvest season and is not easy to rot; training and assistance in business management and financial management; training techniques and marketing strategies online and offline.
\end{abstract}

Keywords: Bogem Syrup; Wringer; Cooling machine; Financial management; Marketing 


\section{PENDAHULUAN}

Di dalam hutan mangrove Surabaya terdapat 202 jenis tanaman dan setiap jenisnya memiliki spesies masing-masing. Tidak semua jenis mangrove dapat dikonsumsi, hanya 17 jenis mangrove yang dapat dimanfaatkan untuk makanan, minuman, obat-obatan dan kosmetik. Pedada (Sonneratia caseolaris) merupakan salah satu penyusun hutan bakau yang berada di sepanjang pantai berlumpur yang mempunyai salinitas rendah. Buah pedada berbentuk bulat, ujung bertangkai, dan bagian dasarnya terbungkus kelopak bunga. Buah ini memiliki diameter antara 6-8 $\mathrm{cm}$ dan biji berjumlah 800-1200 (Chen dkk. 2009). Buah pedada berwarna hijau, dan mempunyai aroma yang sedap. Buah pedada ini tidak beracun dan berasa asam. Buah pedada ini memiliki nama internasionalnya yaitu Crabapple mangrove (Ahmed dkk., 2010). Buah mangrove ini dapat dikonsumsi dan kulit kayunya dapat dimanfaatkan sebagai pewarna kain (Dewi dkk., 2014; Priyono dkk., 2010).

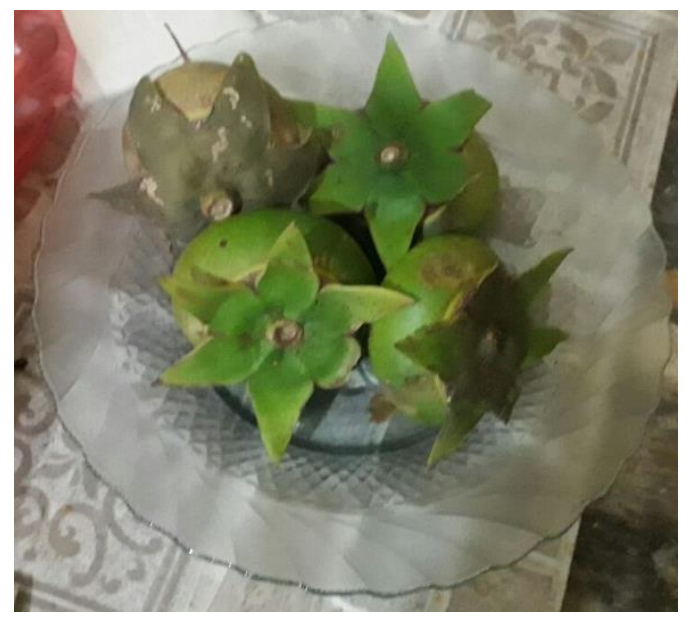

Gambar 1. Buah Mangrove

Kawasan hutan mangrove di Wonorejo Surabaya tidak hanya menjadi habitat untuk beragam jenis burung, tapi juga sumber kehidupan bagi masyarakat sekitar. Kelompok Tani disana membudidayakan produk olahan dari tanaman mangrove. Kelompok Tani Mangrove Wonorejo adalah penggagas dan meproduksi sirup bogem sehingga meningkatkan kearifan lokal kawasan hutan mangrove Wonorejo Surabaya. Produk olahan sirup dari buah papeda mangrove ini memiliki merek dagang yaitu "Bogem". Kelompok Tani Mangrove Wonorejo yang diketuai Bapak Mohson ini berada di Jalan Wonorejo Timur, Kelurahan Wonorejo, Kecamatan Rungkut, Kota Surabaya, Jawa Timur 60296. Kelompok tani ini memiliki anggota kurang lebih 10 orang.

Selain memberdayakan warga dalam pengolahan sirup, beliau juga memberikan edukasi warga untuk pengolahan buah bogem, termasuk cara perawatan hutan mangrove agar buah bogem bisa dipanen maksimal. Saat batang setinggi $15 \mathrm{~cm}$, diusahakan daun tidak sampai rontok. Bila daun rontok maka akan tumbuh lagi dalam waktu lama dan berbuahnya juga menjadi lebih lama.

Produk sirup mangrove Bogem ini memiliki banyak manfaat bagi tubuh. Sirup Bogem ini telah dilakukan kandungan gizinya, yaitu mengandung $1,24 \%$ protein, 0,24\% lemak, $1,74 \%$ karbohidrat, dan 70,6\% vitamin C. Kandungan vitamin $\mathrm{C}$ yang tinggi ini mampu mengobati panas dalam, sariwan, mencegah flu, dan menjaga kestabilan tubuh. Sirup mangrove ini juga dapat mengobati darah tinggi dan gondok juga karena mengadung yodium (Randly, 2006). Pada tahun 2007 juga telah dilakukan uji proksimat dan kelayakan di laboraturium. Sirup karya Bapak Mohson dan kelompok tani mangrove ini dipastikan bebas dari pestisida dan zat kimia lainnya. 


\section{Produksi}

Proses pembuatan sirup mangrove ini dengan tahapan sebagai berikut

1. Buah papeda yang telah matang dikupas terlebih dahulu kulitnya dengan pisau stainless karena buah papeda bersifat asam dan mudah menimbulkan karat.

2. Buah papeda kemudian ditimbang

3. Lalu dimasukkan ke dalam panci dengan komposisi $1 \mathrm{~kg}$ papeda dengan $2 \mathrm{~kg}$ gula dan 2 liter air sampai rebusan mendidih maksimal, sambil diaduk lalu angkat.

4. Kemudian air dan hasil rebusan disaring dengan kain dengan alat sederhana

5. Lalu diperas sampai habis airnya

6. Setelah dingin, dimasukkan sirup ke dalam botol yang telah disterilkan

7. Sirup dikemas dalam botol dan disegel

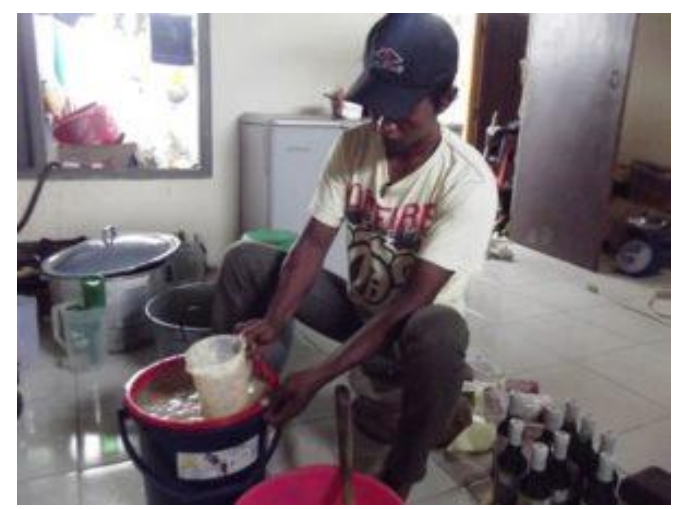

Gambar 2. Proses Pembuatan Sirup Mangrove "Bogem"

Berikut beberapa gambar produk jadi sirup mangrove "Bogem".
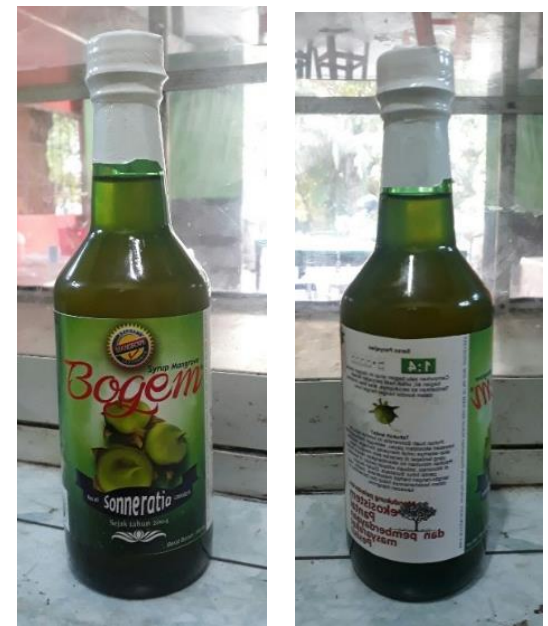

Gambar 3. Sirup mangrove "Bogem" yang Telah Jadi

Produk sirup buah bogem ini telah memiliki berbagai perijinan yakni ijin usaha dan merek dagang. Bapak Mohson menjaga kualitas dan kebersihan produksi untuk menjaga kualitasnya. Dalam satu minggu dapat memproduksi 60-100 liter sirup. Setiap 2,5 liter sirup dibuat dari 2 kilogram gula pasir, 1 kilogram buah bogem, dan 2 liter air. Kemudian dikemas dalam botol dengan ukuran 360 mililiter sehingga didapatkan 7 botol sirup Bogem. Kelompok tani ini juga menyimpan dalam bentuk kemasan sirup ataupun buah yang dibekukan agar bertahan lebih lama.

Alat pemeras yang dirancang diharapkan berkapasitas besar dengan hasil optimal dengan menggunakan metode observasi dan wawancara kebutuhan pemakai serta metode perhitungan terhadap rancang bangun alat pemeras produk olahan tersebut (Maghfurah dan Yulianto, 2016). Tujuan menciptakan alat pemeras adalah agar dapat diterapkan di UKM (Usaha Kecil Menengah) serta untuk dunia industri dapat dijadikan alat yang mudah dan efektif untuk meringankan kerja manusia dan dapat di produksi dengan skala besar (Maghfurah dan Ardiyanto, 2016). 
Secara keseluruhan proses produksi pembuatan sirup Bogem ini belum maksimal dan terdapat hambatan pada saat proses pemerasan dengan manual dan proses penyimpanan buah pedada. Untuk mengatasi masalah tersebut dibutuhkan sentuhan teknologi dan PKM (Program Kemitraan Masyarakat) agar usaha sirup Bogem ini berkelanjutan.

\section{Permasalahan}

Permasalahan mitra dan justifikai pengusul dapat disimpulkan berikut:

1. Dalam proses pembuatan sirup ini terdapat hambatan, yakni pada proses pemerasan yang masih manual. Proses pemerasan menggunakan kain yang digantung dan membutuhkan tenaga yang besar sehingga menyebabkan cepat mengalami kelelahan. Hal ini membutuhkan tenaga kerja yang banyak dan akan kewalahan jika permintaan sirup Bogem tinggi. Semakin tingginya jumlah tenaga kerja maka akan membebani biaya produksi sedangkan harga jual tetap. Bila hal ini diteruskan maka produksi sirup Bogem ini akan turun dan permintaan lama kelamaan akan menghilang.

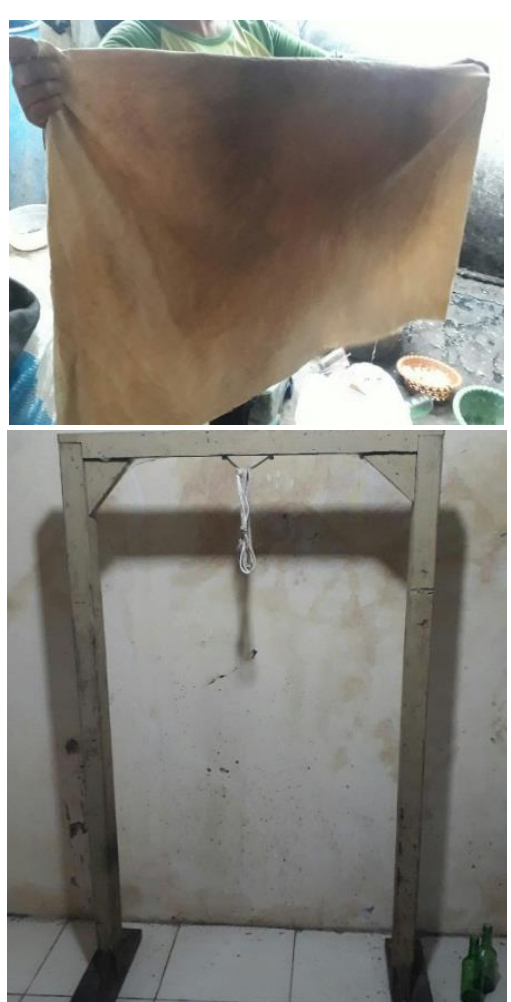

Gambar 4. Alat Pemeras yang

Digunakan

2. Pada saat ini lemari penyimpanan (freezer) ini mengalami kerusakan. Hal ini menyebabkan bila pada musim panen buah bogem harus segera diproses agar tidak busuk sehingga hasil produksi melimpah. Hal tersebut tidak diimbangi dengan penjualan yang naik sehingga kelompok tani dan Bapak Mohson terpaksa menjual dengan harga murah yang berdampak pada menurunnya pendapatan bahkan kerugian. Sebaliknya bila bukan masa panen, buah Bogem ini jumlahnya sedikit sedangkan permintaan cukup tinggi. Hal ini menyebabkan sirup Bogem sulit dicari dan tenaga kerja dari masyarakat sekitar tidak dapat terserap. 


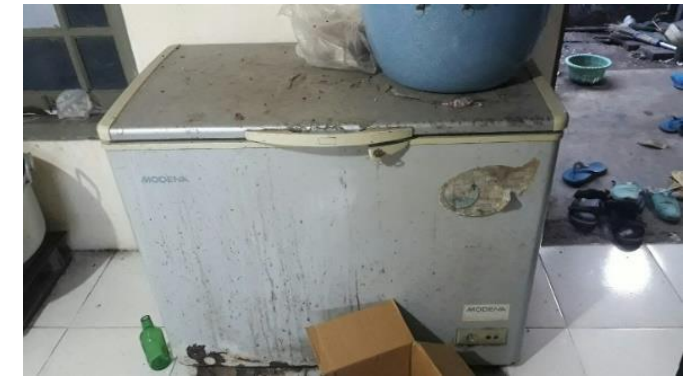

Gambar 5. Mesin Pendingin yang Rusak

3. Pengelolaan usaha yang masih sangat tradisional dan tidak memiliki pembukuan/ pengelolaan keuangan usaha sehingga operasi produksi belum maksimal. Diharapkan dengan manajemen usaha yang baik didapatkan aspek-aspek yang perlu diperbaiki dan ditingkatkan

4. Kurangnya wawsasan mengenai tentang Strategi Pemasaran, seperti penjualan secara online agar dapat memperluas dan meningkatkan penjualan. Dikarenakan selama ini penjualan masih konvensional dengan dijual di toko oleh-oleh dan hasil penjualan tidak meningkat. Belum adanya media pemasaran offline seperti poster, spanduk maupun banner yang menunjukkan identitas usaha sirup Bogem ini.

\section{METODE PELAKSANAAN}

Berdasarkan permasalahan yang dihadapi Mitra Kelompok Tani Mangrove, serta solusi yang ditawarkan, maka metode pelaksanaannya adalah sebagi berikut:

1. Melakukan identifikasi beberapa permasalahan yang dihadapi oleh mitra Kelompok Tani Mangrove melalui metode survei awal, wawancara dengan mitra, dan observasi melihat proses pembuatan sirup Bogem, untuk mengetahui permasalahan yang paling mendesak.
2. Berdasarkan hasil identifikasi permasalahan yang dihadapi, selanjutnya ditentukan beberapa masalah yang mendesak yang harus segera diatasi diantaranya:

a. Membuatkan/pengadaan alat pemeras hasil rebusan buah Bogem sehingga tidak memperlambat proses produksi dan

b. Pengadaan mesin pendingin agar buah Bogem dapat disimpan saat musim panen dan tidak mudah busuk serta sirup Bogem lebih awet.

3. Pelatihan ketrampilan pemakaian alat pemeras dan penggunaan mesin pendingin.

4. Pelatihan ketrampilan Pelatihan Ketrampilan Pembukuan Sederhana dan pengeloaan keuangan usaha.

5. Pelatihan ketrampilan pemasaran, pengusul PKM membantu proses pemasaran dengan cara pelatihan teknik dan strategi pemasaran secara online, seperti Shopee, Tokopedia, Bukalapak atau melalui instgram dan pemasaran secara offline seperti poster, spanduk maupun banner.

6. Metode pendekatan yang dilakukan adalah metode learning by doing. Dalam metode ini Kelompok Tani Mangrove dapat dalam mengikuti pelatihan tidak harus dengan meninggalkan pekerjaannya, akan tetapi dalam proses pelatihan bisa dilaksanakan bersamaan dengan saat melakukan pekerjaannya. Dengan demikian diharapkan pelatihan yang diberikan dapat diterima dan dilaksanakan dengan baik.

7. Metode Partisipatif yang diterapkan dalam proses pelatihan dan pendampingan ini adalah keterlibatan para Kelompok Tani Mangrove secara langsung dalam aplikasinya. 


\section{HASIL DAN PEMBAHASAN}

Langkah-langkah yang telah dilakukan oleh Tim Pelaksana untuk menyelesaikan masalah yang dihadapi adalah sebagai berikut :

1. Tersedianya (diadakannya) alat pemeras hasil rebusan buah Bogem dari bahan stainless agar tidak cepat terjadi karat karena buah Bogem bersifat asam.

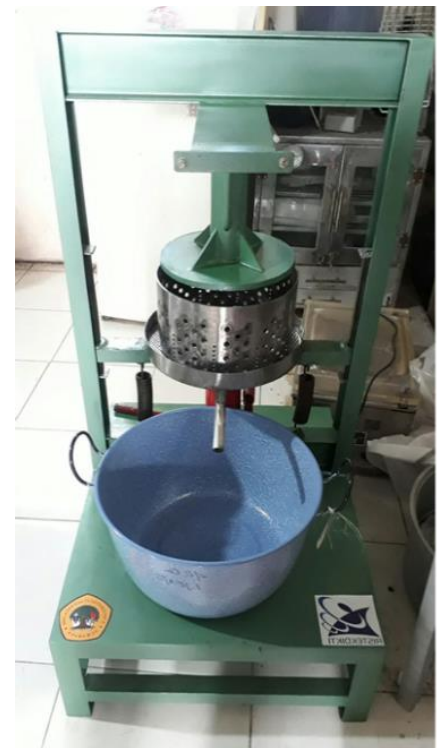

Gambar 6. Alat Pemeras

2. Tersedianya (diadakannya) mesin pendingin (freezer) buah Bogem saat datang musim panen sehingga buah Bogem dapat disimpan dan tidak mudah busuk serta sirup Bogem lebih awet.

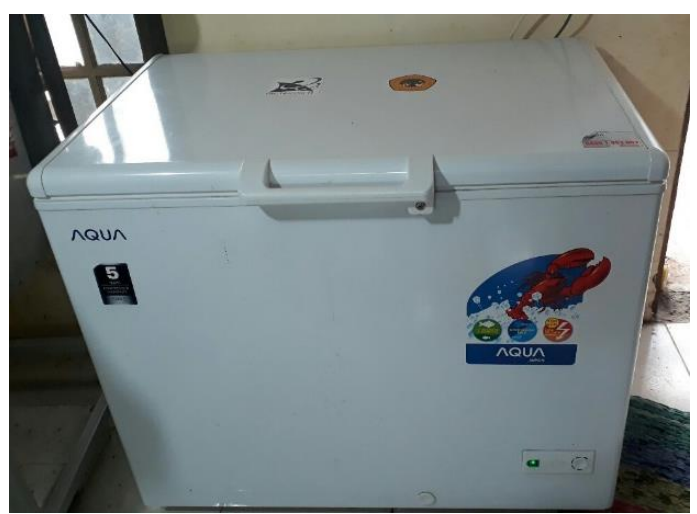

Gambar 7. Mesin Pendingin
3. Pelaksanaan pelatihan penggunaan teknologi tepat guna (alat pemeras dan mesin pendingin) disertai prakteknya.

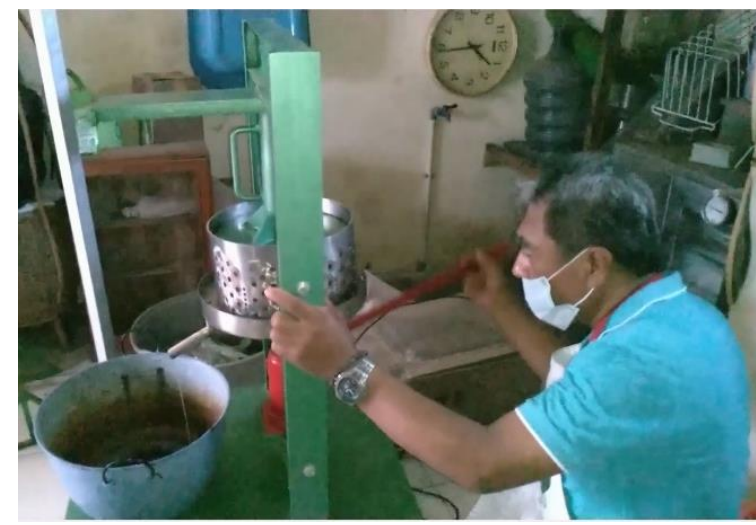

Gambar 8. Pelatihan Penggunaan Alat Pemeras

4. Melaksanakan pelatihan dan pendampingan di bidang manajemen pengelolaan usaha termasuk penyusunan pembukuan sederhana.

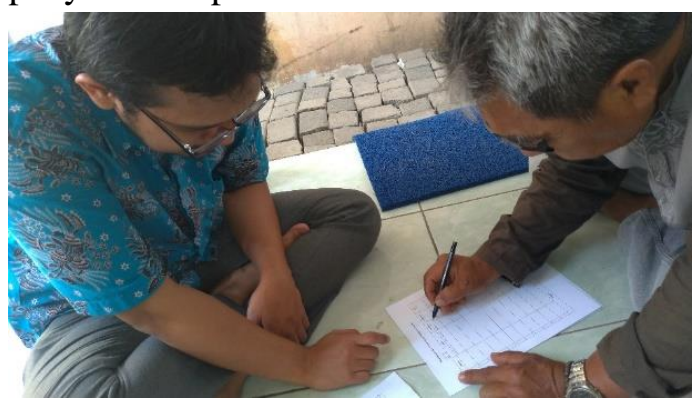

Gambar 9. Pelatihan Manajemen Pembukuan Sederhana

5. Melaksanakan pelatihan dan pendampingan di bidang pemasaran dengan cara Pelatihan Teknik dan Strategi Pemasaran, pemasaran secara online maupun offline. 


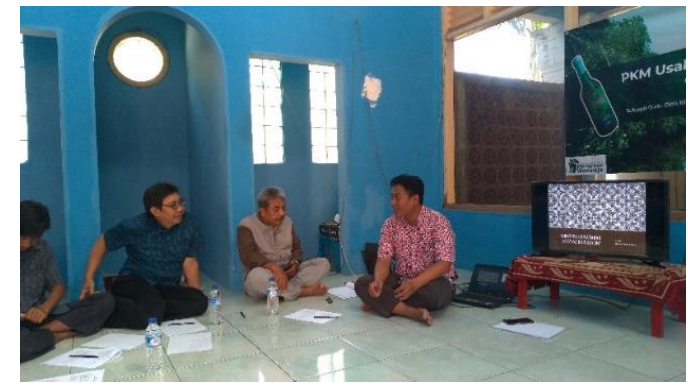

Gambar 10. Pelatihan Strategi

Pemasaran

6. Tersedianya media pemasaran untuk meningkatkan penjualan, secara online, seperti Shopee, Tokopedia, Bukalapak atau melalui instgram yang sedang populer saat ini dan media offline seperti poster, spanduk maupun banner.

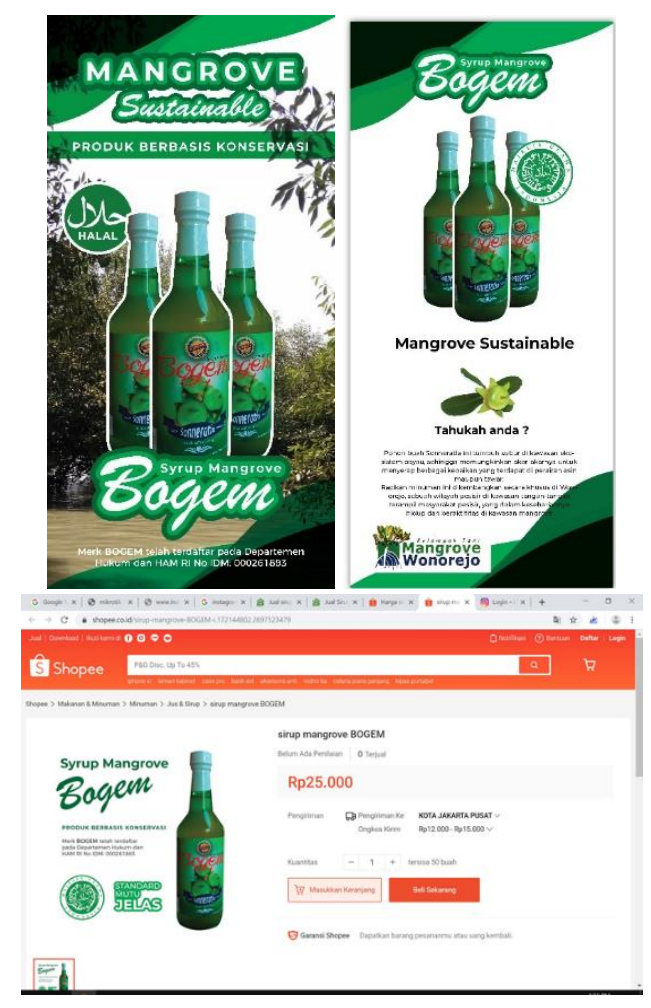

Gambar 11. Media Pemasaran online dan offline

Capaian dari tahap-tahap pengabdian masyarakat PKM ini dapat dirangkum dalam tabel 1.

\section{UCAPAN TERIMA KASIH}

Terima kasih disampaikan kepada Direktorat Riset dan Pengabdian Masyarakat (DRPM), Direktorat Jenderal Penguatan Riset dan Pengembangan, Kementerian Riset, Teknologi, dan Pendidikan Tinggi Republik Indonesia selaku penyandang dana pada pengabdian masyarakat ini.

\section{KESIMPULAN}

Berdasarkan pengabdian masyarakat ini dapast disimpulkan sebagai berikut:

1. Tersedianya (diadakannya) alat pemeras hasil rebusan buah Bogem dari bahan stainless agar tidak cepat terjadi karat karena buah Bogem bersifat asam. Tersedianya (diadakannya) mesin pendingin (freezer) buah Bogem saat datang musim panen sehingga buah Bogem dapat disimpan dan tidak mudah busuk serta sirup Bogem lebih awet. Pelaksanaan pelatihan penggunaan teknologi tepat guna (alat pemeras dan mesin pendingin) disertai prakteknya.

2. Melaksanakan pendampingan (termasuk pelatihan) di bidang manajemen pengelolaan usaha termasuk penyusunan pembukuan sederhana. Melaksanakan pendampingan (termasuk pelatihan) di bidang pemasaran dengan cara pelatihan teknik dan strategi pemasaran, pemasaran secara online maupun offline.

3. Tersedianya media pemasaran untuk meningkatkan penjualan, secara online, seperti Shopee, Tokopedia, Bukalapak atau melalui instgram yang sedang populer saat ini dan media offline seperti poster, spanduk maupun banner. 


\section{DAFTAR PUSTAKA}

Ahmed R, Moushumi SJ, Ahmed H, Ali M, Haq WM, Jahan R, Rahmatullah M. 2010. Serum glucose and lipid profiles in rats following administration of Sonneratia caseolaris (L.) Engl. (Sonneratiaceae) leaf powder in diet. Advances in Natural and Applied Sciences 4(2):171-173.

Chen L, Zan Q, Li Mingguang, Shen J, Liao W. 2009. Litter dynamics and forest structure of the introduced Sonneratia caseolaris mangrove forest in Shenzhen, China. Estuarine, Coastal and Shelf Science 85(2):241-246.

Dewi P.D.P., Sukerti N.W., Ekayani I.A.P.H. 2014. Pemanfaatan Tepung Buah Mangrove Jenis Lindur (Bruguiera Gymnorrizha) Menjadi Kue Kering Putri Salju. Bosaparis (2)1: 1-10.

Maghfurah, F. dan Yulianto, S. 2016. Optimasi Rancang Bangun Alat
Pemeras Sari Buah Jeruk dengan Menggunakan Motor Berdaya 132 Watt. Jurnal FTUMJ. TM - 036. eISSN : $2460-8416$

Maghfurah, F. dan Ardiyanto, T. 2016.

Optimasi Rancang Bangun Alat Pemeras Buah Jeruk dengan Menggunakan Sistem Perputaran Motor Listrik 0,3 Hp. SINTEK VOL 10 NO 1, 11-16.

Priyono A, Ilminingtyas D, Mohson, Yuliani LS, Hakim TL. 2010. Beragam produk olahan berbahan dasar mangrove. Semarang: Kesemat.

Raindly. 2006. Sirup Apel Mangrove. Pustaka Pelajar. Yogyakarta. 